DOI https://doi.org/10.30525/978-9934-26-110-7-53

\title{
КОМУНІКАТИВНА ОСОБИСТІСТЬ СУЧАСНОГО ОФІЦЕРА: ІНТЕРНАЦІОНАЛЬНІ ТА НАЦІОНАЛЬНО-СПЕЦИФІЧНІ РИСИ
}

\author{
Пелепейченко Л. М.
}

доктор філологічних наук, професор, професор кафедри філології, перекладу та стратегічних комунікацій Начіональна академія Начіональної гвардї Украӥни

\author{
Ревуцька С. М. \\ кандидат педагогічних наук, доцент, \\ професор кафедри філології, перекладу та стратегічних комунікацій \\ Національна академія Начіональної гвардї України \\ м. Харків, Україна
}

Поширення антропоцентричного підходу до вивчення мовних явищ, дослідження в царині когнітивної та прагматичної лінгвістики переконливо довели, що мову необхідно пізнавати не як абстрактну сутність, а в контексті життя і діяльності людини. У лінгвістиці XX століття активно досліджували питання про те, як фактор людини відбивається в мові, в сучасних дослідженнях ракурс дещо змінився: основна увага зосереджена на осмисленні питання про те, як фактор мови відбивається в діяльності людини. Термін «мова» інтерпретується не тільки як різнорівнева система одиниць, що слугує основним засобом спілкування в суспільстві, а ще і як використання одиниць, спрямоване на досягнення поставлених цілей, моделювання певних стратегій і тактик, як засіб вербалізації картини світу та аксіологічного досвіду мовної спільноти. Носієм сукупності названих ознак $є$ комунікативна особистість, з одного боку, унікальна для кожної окремої постаті, з другого, - така, що має деякі риси, типові для нації, професії та соціальних прошарків, до яких вона належить. Пізнання характеристик комунікативних особистостей різних типів може прояснити багато питань власне лінгвального плану від особливостей розшарування мовних одиниць до способів реалізації їхнього прагматичного потенціалу в живому спілкуванні. Проте воно має значення не тільки в лінгвістичному аспекті. Створення цілісних уявлень про комунікативну особистість офіцера $є$ важливим у зв'язку з низкою завдань: побудови технологій професійного становлення курсантів (педагогічний аспект), формування еталонних стереотипів військових 
(соціальний аспект), виборі комунікативних стратегій упливу в комунікації (комунікативний аспект).

Незважаючи на значний інтерес до названої проблеми, багато питань залишаються на сьогодні вичерпно не з'ясованими. Поміж інших до них належить питання про інтернаціональні та національно-специфічні риси професійної комунікативної особистості, про механізми іії еволюції, що відбувається під впливом соціальних змін, і багато інших.

Мета цієї роботи - обгрунтувати розмежування інтернаціональних і національно-специфічних рис професійної комунікативної особистості офіцера.

Пояснимо поняття «комунікативна особистість» у нашій інтерпретації, оскільки воно в теоретичних джерелах трактується порізному $[1 ; 2 ; 3]$. Його розглядаємо як результат еволюції поняття «мовна особистість», динаміку якого ми вже висвітлювали в своїх працях: «...від розмежування мовної особистості автора твору та персонажа - до характеристики мовної особистості як структури, утвореної декількома рівнями, що забезпечують здатність сприймати і продукувати тексти далі до опису типів мовних особистостей за ознаками мовної здатності, соціальних характеристик, поведінкових реакцій - до опису мисленнєвих механізмів реалізації мовної здатності» $[3$, с. 8]. У нашій праці поняття «комунікативна особистість» тлумачиться як сукупність власне мовних ознак, притаманних конкретній постаті, і тих, що становлять іiі особистий комунікативний стиль і проявляються в дискурсивних практиках у наративах, персуазивах, рефутативах, комунікативній поведінці як реакції на різні мовні подразники - від компліменту до реакції на фальшиві повідомлення та образи. Другий аспект ми назвали дискурсивним. Зрозуміло, що кожний окремий військовий, як і представник будь-якої професії, являє собою унікальну, неповторну комунікативну особистість, і все ж у ній є риси, що незмінно притаманні будь-якому іншому представнику тієї самої професії. Ми розрізняємо еталонну комунікативну особистість - абстрактну постать, якій притаманні тільки позитивні професійні риси, і реальну, яка може бути носієм і деяких негативних рис. У цьому дослідженні інтернаціональні і національно-специфічні риси розмежовуємо тільки стосовно еталонної комунікативної особистості офіцера.

Риси еталонної особистості офіцера представлені передусім у підручниках і посібниках для курсантів та офіцерів [4; 5]. Ознайомлення iз змістом згаданих видань засвідчило, що когнітивну основу професійної особистості офіцера, у тому числі і комунікативної, становлять ціннісні пріоритети соціуму, а саме: ВІДВАГА, ВІДДАНІСТЬ 
СПРАВІ, ВІЙСЬКОВЕ ЛІДЕРСТВО, ЗАХИСТ, ОБОВ'ЯЗОК, ПАТРІОТИЗМ, ПОВАГА, САМОПОЖЕРТВА, ВІРНІСТЬ ВІЙСЬКОВІЙ ПРИСЯЗІ, ЧЕСТЬ, ЧЕСНІСТЬ. Названі риси визначають особливості комунікативної поведінки офіцерів у різних ситуаціях, а також і деякі ознаки використання ними ресурсів мови. Перелічені риси, безумовно, $\epsilon$ інтернаціональними. Однак деякі 3 них містять певну суперечність: 3 одного боку, вони $є$ інтернаціональними, 3 другого, - національноспецифічними. До таких рис належить ПАТРІОТИЗМ. Безсумнівно, кожен офіцер незалежно від країни, в якій він служить, має бути патріотом, але головне - саме своєї країни. Із цього твердження випливає, що національно-специфічним є фактор когнітивного плану: історичні основи і джерела формування особистості офіцера. Питання про те, як саме вони визначають комунікативну поведінку офіцера потребує спеціального дослідження, яке виходить за межі завдань нашої роботи. Звернемося до результатів аналізу власне мовного аспекту комунікативної особистості. Зауважимо, що аналіз проводився на матеріалі промов військових лідерів різних країн і художніх кінофільмів.

На вербально-семантичному рівні [2] еталонному типу комунікативної особистості офіцера притаманна чіткість логічність і лаконічність вираження думок; на тезаурусно-когнітивному - професійна та правова обізнаність, володіння загальнонаціональним когнітивним досвідом; на мотиваційно-прагматичному рівні - вміння здійснювати мовний вплив, апелюючи до сучасних соціальних ціннісних пріоритетів: демократичності, верховенства закону і права, етичності.

Аналіз дискурсивного аспекту професійної комунікативної особистості офіцера засвідчив такі інтернаціональні риси. Еталонний тип офіцера - людина комунікабельна. Офіцер добре володіє навичками публічного спілкування. Найбільш виразно ораторські вміння сучасного офіцера репрезентовані в промові американського адмірала Уільяма Х. МакРейвена, що подана в мережі Інтернету під назвою «Промова, яка неймовірно надихає». Виступаючи перед випускниками Техаського університету в Остіні, 17 травня 2014 року, адмірал дає напуття молодим людям, побудоване на утвердженні основних ціннісних пріоритетів будьякого цивілізованого суспільства: «Змініть світ на краще». Супроводжуючи свій виступ відеороликами, він розповідає про різні ситуації у підготовці морських котиків. Кожна із розповідей закінчується висновком про те, що треба зробити, щоб світ став кращим. Промова офіцера демонструє і власне мовні ознаки еталонної комунікативної особистості: чіткість та логічність мовлення, метафоричність, виразність, і власне дискурсивні: орієнтованість на аудиторію, надихання на активну і відповідальну службу, зв'язок із нагальними проблемами сучасності. 
Із комунікативних стратегій для еталонної особистості обов'язковою $\epsilon$ стратегія ввічливості в будь-яких ситуаціях; у службовій діяльності стратегія імперативу, стратегія пояснення; якщо цього вимагає ситуація, еталонний тип офіцера вміло використовує стратегії надихання та переконання.

Специфічними є реакції еталонного типу на комплімент, агресію та спір. Реакція на комплімент - зважена, позбавлена підвищеної емоційності, а тим паче екзальтованості. Еталонний тип офіцера занижує ступінь позитиву, висловлений у компліменті (мовне вираження відповідної тактики - Кожен вчинив би так само). У відповідь на агресію в комунікації офіцер спочатку демонструє холодну ввічливість, зберігає спокій, не підвищує голос, не допускає словесної перепалки, проте відповідає чітко, у той чи інший спосіб демонструючи стратегію домінування. У спорі еталонний тип використовує передусім логічні аргументи; помилкові погляди спростовує фактами, не вдається до маніпулятивних тактик спору та некоректних прийомів. Він важко йде на компроміси, допускаючи їх тільки в складних ситуаціях. Спір, як правило, доводить до перемоги, хоча не акцентує увагу на факті своєї переваги.

Узагальнюючи результати дослідження відзначимо, що переважна більшість рис професійної комунікативної особистості офіцера $є$ інтернаціональними, а національну специфіку визначають світоглядні ознаки країни, в якій він служить, та її комунікативна культура.

Перспективою дослідження вважаємо встановлення концептуального простору історичних факторів, що впливають на формування національно-специфічних рис комунікативної особистості офіцера.

\section{Література:}

1. Карасик, В.И. Языковой круг: личность, концепты, дискурс. М.: ГНОЗИС, 2004. 389 с.

2. Караулов Ю.Н. Русский язык и языковая личность. Изд. 6-е. М.: Изд-во ЛКИ, 2007. 264 с.

3. Комунікативна особистість військовослужбовця Національної гвардії України в сучасному соціальному контексті: монографія / Пелепейченко Л.М. та ін.; за ред. Л.М. Пелепейченко. Харків: Національна академія НГУ, 2014. 221с.

4. Generic Officer Professional Military Education REFERENCE CURRICULUM: веб-сайт. URL: https://cutt.ly/amxYK2T.

5. Ranger Handbook / Ranger training brigade. United States Army Infantry School Fort Benning, 2000. 248 p. 